\title{
ROBO2 wt Allele
}

National Cancer Institute

\section{Source}

National Cancer Institute. ROBO2 wt Allele. NCI Thesaurus. Code C126775.

Human ROBO2 wild-type allele is located in the vicinity of 3p12.3 and is approximately $1743 \mathrm{~kb}$ in length. This allele, which encodes roundabout homolog 2 protein, is involved in axon guidance, cell migration and lig and binding. Chromosomal anomalies, including $t(Y ; 3)(p 11 ; p 12)$, that cause dominant-negative mutations in this gene are associated with vesicoureteral reflux. 